\title{
Effect of Integrated Nutrient Management on Yield and Economics in Summer Sweet Corn (Zea mays L. saccharata)
}

\author{
B. Mohana Rao, G.C. Mishra*, Sagar Maitra and Rahul Adhikary
}

M.S. Swaminathan School of Agriculture,Centurion University of Technology and Management, Paralakhemundi, Odisha, India *Corresponding author: gcmishra@cutm.ac.in (ORCID ID: 0000-0003-0803-7169)

Paper No. 812

Received: 07-10-2019

Revised: $12-01-2020$

Accepted: 29-02-2020

\begin{abstract}
The field experiment was carreied out at Research Farm, Bagusala, M.S. Swaminathan School of Agriculture, Centurion University of Technology and Management during summer, 2018. The soil was sandy loam in texture, slightly acidic in reaction ( $\mathrm{pH} 6.8$ ) and low in available $\mathrm{N}(158.83 \mathrm{~kg} / \mathrm{ha})$ and $\mathrm{P}_{2} \mathrm{O}_{5}$ $(10.82 \mathrm{~kg} / \mathrm{ha})$ and medium in available $\mathrm{K}_{2} \mathrm{O}(147.67 \mathrm{~kg} / \mathrm{ha})$. The randomized complete block design was adopted with three replications for testing 8 treatments. They were consisted of $100 \%$ recommended dose of fertilizer ( DF) @ 120-60-60 kg of N-P $\mathrm{O}_{5}-\mathrm{K}_{2} \mathrm{O} / \mathrm{ha}$ ), 100\% RDF + bio fertilizer consortia (Azotobactor + Azosporillum + phosphobacter) $@ 15 \mathrm{~kg} / \mathrm{ha}, 50 \%$ recommended dose of nitrogen (RDN) through farm yard manure (FYM) + 50 \% RDF + bio fertilizer consortia (BFC) @15 kg/ha, 50 \% RDN through vermi compost $(\mathrm{VC})+50 \%$ RDF + BFC @15 kg/ha, 75 \% RDF + $25 \%$ RDN through FYM, 75 \% RDF + $25 \%$ RDN through VC, $75 \%$ RDF + 25 \% RDN through FYM + BFC @15 kg/ha and 75 \% RDF + 25 \% RDN through VC + BFC@15 kg/ha. The yield attributes such as number of cobs/plant, cob length, cob girth and cob weight along with green cob and forage yield were remarkably influenced by integrated nutrient management treatments. Application of $75 \%$ RDF + $25 \%$ RDN (VC) + BFC @15 kg/ha recorded the highest yield attributes and green cob (12.01 t/ha) and fodder ( $₹ 16.52 \mathrm{t} / \mathrm{ha}$ ) yield. It was followed by $100 \% \mathrm{RDF}+\mathrm{BFC}$ $@ 15 \mathrm{~kg} /$ ha producing the green cob and forage yield of 11.67 and $16.17 \mathrm{t} / \mathrm{ha}$, respectively. The maximum net return (Rs. 164206/ ha) and benefit cost ratio (1.92) was obtained with integration of $100 \%$ RFD (12060-60 kg of N, $\mathrm{P}_{2} \mathrm{O}_{5}$ and $\mathrm{K}_{2} \mathrm{O} / \mathrm{ha}$ ) and BFC (Azotobactobacter + Azosporillum + posphobacter) @15 kg/ha.

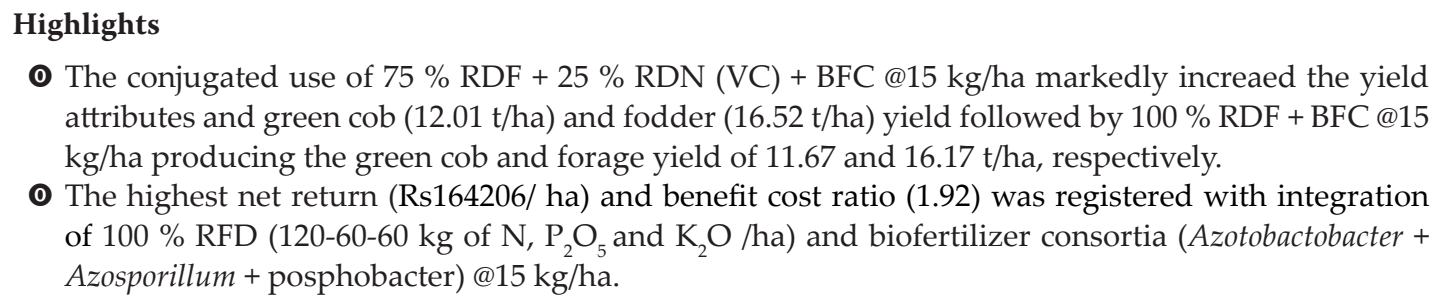

Keywords: Recommended dose of fertilizer, recommended dose of N, farm yard manure, vermi compost, biofertilizer consortia, yield, economics and sweet corn

In India, sweet corn is grown in limited area by both farmers and private sectors to meet the demand of consumption at raw stage after roasting. In order to improve the economic condition of poor farmers, the scope of growing sweet corn is well realised. Non availability of appropriate production technology is the major constraint for its popularization among Indian growers. The higher productivity of sweet corn is closely associated with the nutrient management strategy. Sweet corn is an exhaustive crop like maize grain crop and removes greater amount of plant nutrients from soil after harvest. It requires to replenish such nutrients to soil in an integrated manner for sustaining crop production. The judicious use of nutrients in suitable combination of organic and inorganic sources is beneficial to achieve the economical yield and maintain soil heath. The use 
of recommended dose of NPK is found increasing the yield of sweet corn (Sunitha and Reddy 2012). However, NPK fertilizer in combination with organic manure through FYM or vermi compost has resulted in boosting the green cob yield of sweet corn (Mohammadi et al. 2017 and Canatoy 2018). Moreover, application of bio fertilizer with NPK fertilizer increases the efficiency of inorganic fertilizer by $50 \%$ as observed by Mukhlis and Lestari, 2013. The favourable effect of NPK with organic manure (FYM and vermicompost) and biofertilizer in sweet corn has been reported by several workers (Harish et al. 2012; Shobana and Imyavaramban 2012; Rasool et al. 2015; Singh et al. 2018 and Rathod et al. 2018). Therefore, the present experiment was carried out with various proportion of NPK levels combined with different organic sources and mixed microbial inoculants of Azotobacter, Azospirillum and phosphorus solubilising bacteria with an aim to find out a suitable location specific nutrient management strategy for sweet corn in southern parts of Odisha, India.

\section{MATERIALS AND METHODS}

The field experiment was conducted at Research Farm, Bagusala, M.S. Swaminathan School of Agriculture, Centurion University of Technology and Management, Paralakhemundi Odisha, in summer during 2018. The soil of experimental plot was sandy loam in texture with $\mathrm{pH}$ of 6.8 containing available $\mathrm{N}, \mathrm{P}_{2} \mathrm{O}_{5}$ and $\mathrm{K}_{2} \mathrm{O}$ of $158.83,10.82$ and $147.67 \mathrm{~kg} \mathrm{ha}^{-1}$, respectively. The trial was laid out in randomized complete block design with three replications and eight treatments in plot size of $5.0 \mathrm{~m} \times 4.0 \mathrm{~m}$. The details of nutrient management treatments were comprised of $100 \%$ recommended fertilizer dose RDF (120-60-60 kg N, $\mathrm{P}_{2} \mathrm{O}_{5}$ and $\mathrm{K}_{2} \mathrm{O} /$ ha), $100 \%$ RDF + bio fertilizer consortia (Azotobactor + Azosporillum + posphobacter) @15 kg/ha, $50 \%$ recommended dose of $\mathrm{N}$ (RDN) through farm yard manure(FYM) $+50 \%$ RDF + bio fertilizer consortia (BFC) @15 kg/ha, 50\% recommended N through vermi compost (VC) + 50\% RDF + BFC@15 kg/ ha, 25\% RDN through FYM + 75\% RDF 25\% RDN through VC $+75 \%$ RDF, 25\% RDN through FYM + $75 \%$ RDF + BFC @15 kg/ha and $25 \%$ RDN through VC + 75\% RDF + BFC@15kg/ha. The sweet corn hybrid sugar-75 was sown on 10 th February, 2018 with spacing of $50 \mathrm{~cm}$ from row to row and $30 \mathrm{~cm}$ from seed to seed. At sowing, full $\mathrm{P}_{2} \mathrm{O}_{5}$, half $\mathrm{K}_{2} \mathrm{O}$ and one third nitrogen were applied as basal as per the treatment specification. The organic sources of nutrients like farm yard manure (FYM) containing $0.497 \% \mathrm{~N}, 0.241 \% \mathrm{P}_{2} \mathrm{O}_{5}$ and $0.463 \% \mathrm{~K}_{2} \mathrm{O}$ and vermi compost (VC) with $1.499 \% \mathrm{~N}, 0.631 \% \mathrm{P}_{2} \mathrm{O}_{5}, 1.124$ $\mathrm{K}_{2} \mathrm{O}$ and BFC (Azotobactor + Azosporillum + Pospho bacteria) @15kg/ha were applied at sowing as per the treatments specifications. In first top dressing, one third $\mathrm{N}$ and $25 \% \mathrm{~K}_{2} \mathrm{O}$ were applied according to treatments at 30 days after sowing (DAS) at knee high stage. Similarly as per the tretment requirement, the final dressing of one third $\mathrm{N}$ and $25 \% \mathrm{~K}_{2} \mathrm{O}$ was done at tasselling stage. The sources of fertilizer for $\mathrm{N}, \mathrm{P}$ and $\mathrm{K}$ were urea, single super phosphate and muriate of potash. All cultural operations were performed as per the recommended practie. The green cob was plucked two times for table purpose. After final plucking, the crop was harvested as green fodder purpose. The biometric observation on crop growth, yield attributes and yield were recorded at plucking of cob along with green forage yield at harvesting.

\section{RESULTS AND DISCUSSION}

\section{Effect of INM treatments on yield attributes}

The data on yield attributes of sweet corn presented in Table 1 indicated that cob length and cob weight were significantly reflected with nutrient management treatments. The nutrient management treatments failed to exhibit significant effect on number of cobs/plant and cob girth. The maximum number of cobs/plant (1.27) was observed in $75 \%$ RDF + 25\% RDN (VC) + BFC @15kg/ha closely followed by $75 \%$ RDF + 25\% RDN(FYM) + BFC $@ 15 \mathrm{~kg} / \mathrm{ha}(1.25)$. Application of 75\% RDF + 25\% RDN (VC) + BFC @15kg/ha gave the highest cob length $(23.57 \mathrm{~cm})$ which was at par with $50 \%$ RDN (VC) $+50 \% \mathrm{RDF}+\mathrm{BFC} @ 15 \mathrm{~kg} / \mathrm{ha}(23.22 \mathrm{~cm})$ and $50 \%$ RDN (FYM) + 50\% RFD + BFC @15kg/ha $(23.20 \mathrm{~cm})$. The minimum cob length was noticed at $100 \%$ RFD @120-60-60 kg NPK/ha (21.27 cm). Nutrient management treatments had no significant effect on cob girth. The maximum cob girth was obtained with $75 \%$ RDF +25\% RDN (VC) + BFC @15kg/ ha $(17.80 \mathrm{~cm})$ followed by $75 \% \mathrm{RDF}+25 \% \mathrm{RDN}$ $(\mathrm{FYM})+$ BFC @15kg/ha and 75\% RDF + 25\% RDN $(\mathrm{FYM})+$ BFC @15 kg/ha $(17.77 \mathrm{~cm})$. The combined 
Table 1: Effect of nutrient management treatments on yield attributes of sweet corn

\begin{tabular}{|c|c|c|c|c|}
\hline Treatments & Cobs/ plant & Cob length $(\mathrm{cm})$ & Cob girth $(\mathrm{cm})$ & Cob weight (g) \\
\hline $100 \%$ Recommended dose of fertilizer (RDF) & 1.21 & 21.27 & 17.13 & 331.00 \\
\hline $100 \% \mathrm{RDF}+\mathrm{BFC}$ & 1.23 & 22.30 & 17.20 & 344.33 \\
\hline $50 \% \operatorname{RDN}(\mathrm{VC})+50 \%$ RFD & 1.21 & 23.22 & 16.97 & 320.33 \\
\hline $75 \%$ RDF + 25 \% RDN (FYM ) & 1.22 & 22.23 & 17.50 & 360.00 \\
\hline $75 \%$ RDF + $25 \%$ RDN ( VC) + BFC & 1.27 & 23.57 & 17.80 & 365.33 \\
\hline $\operatorname{SEM}( \pm)$ & 0.06 & 0.36 & 0.37 & 14.03 \\
\hline $\mathrm{CD}(\mathrm{P}=0.05)$ & NS & 1.10 & NS & 42.62 \\
\hline
\end{tabular}

$R D F=$ Recommended fertilizer dose, BFC=Bio fertilizer consortia (Azotobactor + Azosporillum + Posphobacter $), R D N=$ Recommended dose of nitrogen, FYM = Farm yard manure, $V C=$ Vermi compost.

Table 2: Yield, harvest index and economics of sweet corn as affected by integrated nutrient management treatments

\begin{tabular}{|c|c|c|c|c|c|c|}
\hline Treatments & $\begin{array}{r}\text { Green cob } \\
\text { yield (t/ha) }\end{array}$ & $\begin{array}{l}\text { Green forage } \\
\text { yield (t/ha) }\end{array}$ & $\begin{array}{l}\text { Harvest } \\
\text { index }(\%)\end{array}$ & $\begin{array}{l}\text { Gross return } \\
\text { (₹/ha) }\end{array}$ & $\begin{array}{l}\text { Net Profit } \\
\text { (₹/ha) }\end{array}$ & $\begin{array}{l}\text { Benefit : } \\
\text { cost ratio }\end{array}$ \\
\hline $100 \%$ Recommended dose of fertilizer (RDF) & 10.98 & 16.10 & 40.55 & 235712 & 151772 & 1.81 \\
\hline $50 \%$ RDN (FYM) + 50\% RFD & 9.54 & 14.27 & 40.07 & 205055 & 110973 & 1.18 \\
\hline $50 \%$ RDN (VC) + 50\% RFD & 10.34 & 15.37 & 40.22 & 222237 & 107321 & 0.93 \\
\hline $75 \%$ RDF + $25 \%$ RDN (FYM) + BFC & 11.28 & 15.83 & 41.61 & 241378 & 151618 & 1.69 \\
\hline $75 \%$ RDF + $25 \%$ RDN (VC) + BFC & 12.01 & 16.52 & 42.10 & 256656 & 156478 & 1.56 \\
\hline SEM $( \pm)$ & 0.49 & 0.77 & 1.38 & - & - & - \\
\hline $\mathrm{CD}(\mathrm{P}=0.05)$ & 1.48 & 2.33 & 4.18 & - & _- & _- \\
\hline
\end{tabular}

RFD $=$ Recommended fertilizer dose, BFC $=$ Bio fertilizer consortia $($ Azotobactor + Azosporillum + Posphobacter $)$, RDN $=$ Recommended dose of nitrogen, FYM = Farm yard manure, $V C=$ Vermi compost.

Seeling price of produce - Green $c o b=₹ 20000 / t$ and green forage $=₹ 1000 / t$

application of $75 \% \mathrm{RDF}+25 \% \mathrm{RDN}(\mathrm{VC})+\mathrm{BFC}$ $@ 15 \mathrm{~kg} / \mathrm{h}$ a produced the highest cob weight (365.33 g). It was statistically at par with all other treatments except 50 \% RDN@60 kg N/ha (FYM) + 50\% RFD + BFC@15kg/ha (302.33 g). The favourable effect of integration of inorganic, organic and bio fertilizers in enhacing the yield attributes of sweet corn might be due to improvement in crop growth parameters that resulted in better translocation, utilization and partitioning of photosynthates. However, integrated use of nutrients influenced the soil physico-chemical and biological properties there by accomplished the better availability, absorption and utilization of nutrients thus, increased yield attributes. This results of present experiment are in close harmony with the findings of Rathod et al. 2018 and Singh et al. 2018.

\section{Effect of INM treatments on yield}

The data depicted in Table 2 showed that nutrient management treatments remarkably affected the green cob yield of sweet corn. The highest green cob yield (12.01 t/ha) was recorded in 75\% RDF + $25 \%$ RDN (VC) + BFC @ $15 \mathrm{~kg} / \mathrm{ha}$ which was found at par with 100\% RDF + BFC @15kg/ha (11.67 t/ ha) and 75\% RDF +25\% RDN @30kgN/ha (FYM) + BFC@15 kg/ha(11.28 t/ha), 75\% RFD + 25\% RDN $@ 30 \mathrm{~kg} \mathrm{~N} / \mathrm{ha}(\mathrm{FYM})+$ BFC @15kg/ha (11.03t/ha) and 100\% RDF (120-60-60 kg NPK/ha). Integrated nutrient management treatments had no significant 
effect on green forage yield. Application of 75\% RDF +25\% RDN@30kg N/ha (VC) + BFC@15 kg/ha resulted in the maximum green forage yield (16.52 t/ha) followed by 100\% RDF (120-60-60 kg NPK/ha) + BFC (16.17 t/ha) and 100\% RDF (16.10/ha). The maximum harvest index was obtained with $75 \%$ RDF +25\% RDN@ $30 \mathrm{~kg}$ N/ha (VC) + BFC @15 kg/ ha $(42.10 \%)$ followed by 100 RDF + BFC@15 kg/ha $(41.92 \%)$. Increase in yield attributes of sweet corn positively reflected the green cob yield in integrated nutrient management treatments. The judicious use of inorganic nutrients, organic manure and bio fertilizers had the synergistic effect on availability of applied nutrienst in soluble form that favoured better utilization of it thus, increased sink capacity through better nutrient uptake by crop. It is in agreement with the findings of Harish et al. (2012); Shobana and Imyavaramban (2012) and Rathod et al. (2018).

\section{Effect of INM treatments on economics}

The integration of 75\% RFD + 25\% RDN @ 30kg N/ ha (VC) + BFC@15 kg/ha registerd the highest gross return (₹ 256656/ ha) followed by 75\% RDF + 25\% RDN (FYM) + BFC@ 15 kg/ha (₹ 249646/ha). This was possible owing to enhancement of green cob and forage yield which directly influenced the gross return. But the net return ( $₹ 164206 /$ ha) and benefit cost ratio (1.92) were maximum with combination of $100 \%$ RDF + BFC @ $15 \mathrm{~kg} / \mathrm{ha}$ and followed by $75 \%$ RDF + $25 \%$ RDN (FYM) + BFC @15 kg/ha recording the net return of ₹ 156478 / ha. This was due appreciable cob and green fodder yield obtained with combined use of recommended dose of fertilizers and biofertilizer consortia (Azotobactor + Azosporillum + phosphobacter). Moreover, the chemical fertilizer and biofertilizer sources are cheaper in comparison to vermi compost and farm yard manure. However, the inorganic sources of nutrients are required in less quantity to supply recommended dose of nutrient which reduced the transportation cost. The conjugated application of $100 \%$ RDF and biofertilizer consortia assured the maximum net return and benefit cost ratio due to the reduced cost of cultivation. It is in accordance with the views of Rathod et al. (2018).

\section{CONCLUSION}

The combined application of $75 \%$ recommended dose of fertilizer with $25 \%$ recommended dose of nitrogen @ 30kg N/ha through vericompost and biofertilizer consortia (Azotobactor + Azosporillum + phosphobacter)@15 kg/ha enhanced the yield attributes and green cob and forage yield of sweet corn. The integration of $100 \%$ RDF (120-60-60 kg of $\mathrm{N}, \mathrm{P}_{2} \mathrm{O}_{5}$ and $\mathrm{K}_{2} \mathrm{O} / \mathrm{ha}$ ) + biofertlizer consortia (Azotobactor + Azosporillum + posphobacter) @15 kg/ ha registered the maximum net profit and benefit cost, cost ratio and increased the economics in sweet corn.

\section{REFERENCES}

Canatoy, R.C. 2018. Dry Matter Yield and NPK Uptake as Influenced by Fertilizer Application. Asian Journal of Soil Science and Plant Nutrition, 3(3): 1-10.

Harish, C.K., Singh, V., Shri Ram and Amit, B. 2012. Nutrient management on soil health, nutrient uptake and yield of maize under temporary submerged condition in mollisol. Madras Agricultural Journal, 99(7-9): 548-552.

Mohammadi, N.K., Pankhaniya, R.M., Joshi, M.P. and Patel, K.M. 2017. Influence of inorganic fertilizer and vermicompost and biofertilizer on yield and economic of sweet corn and nutrient status in soil. International Journal of Applied Research, 3(5): 183-186.

Mukhlis and Lestari, Y. 2013. Effects of biofertilizer "m-star" on land productivity and growth of sweet corn in acid sulphate soil of swamp land. Agrivita, 35(3): 242 - 248.

Rasool, S., Kanth, R.H., Hamid, S., Raja W., Alie, B.A. and Dar. Z.A. 2015. Influence of integrated nutrient management on growth and yield of sweet corn (Zea mays L. saccharata) under temperate conditions of Kashmir valley. American Journal of Experimental Agriculture, 7(5): 315-325.

Rathod, M., Bavalgave, V.G ., Tandel. B and Gudadhe, N.N. 2018. Effect of spacing and INM practices on growth, yield and economics of rabi of sweet corn (Zea mays L. saccharata Sturt) under south Gujarat condition. International Journal of Chemical Studies, 6(5): 247-250.

Shobana, R. and Imyavaramban, V. 2012. Integrated nutrient management in hybrid maize (Zea mays L.) Cv Pioneer 30. Plant Archieves, 8(1): 433-434.

Singh, S., Singh, V., Shukla . R.D and Singh, K. 2018. Effect of fertilizer levels and bio-fertilizer on green cob yield of corn (Zea mays L.). International Journal of Chemical Studies, 6(2): 2188-2190.

Sunitha, N. and Reddy, M. 2012. Effect of graded nutrient levels and timing nitrogen application on yield and quality of sweet corn (Zea mays L.). Madras Agricultural Journal, 99(4-6): 240-243. 